\title{
Biochemical Basis of Resistance in Rice against Brown and White Backed Planthopper
}

\author{
K.N. Ashrith ${ }^{1 *}$, A.G. Sreenivas ${ }^{1}$, G.S. Guruprasad ${ }^{2}$, \\ S.G. Hanchinal ${ }^{1}$ and D. Krishnamurthy ${ }^{3}$ \\ ${ }^{1}$ Department of Agricultural Entomology, College of Agriculture, University of Agricultural \\ Sciences, Raichur, 584104, Karnataka, India \\ ${ }^{2}$ Entomology, ARS, Gangavathi, Karnataka, India \\ ${ }^{3}$ Department of Agronomy, College of Agriculture, University of Agricultural Sciences, \\ Raichur, 584104, Karnataka, India \\ *Corresponding author
}

A B S T R A C T

\begin{tabular}{|l|}
\hline Key w o r d s \\
Nilaparvata lugens, \\
$\begin{array}{l}\text { Sogatella furcifera, } \\
\text { Biochemicals, } \\
\text { Resistance. }\end{array}$ \\
\hline Article Info \\
\hline $\begin{array}{l}\text { Accepted: } \\
17 \text { September } 2017 \\
\text { Available Online: } \\
10 \text { October } 2017\end{array}$ \\
\hline
\end{tabular}

The experiment was carried out to assess the biochemical basis of resistance in response to the infestation by brown planthopper (BPH), Nilaparvata lugens (Stal) and white backed planthopper (WBPH), Sogatella furcifera (Horvath) in transplanted (TPR) and direct seeded (DSR) rice ecosystem. The changes of various biochemical constituents such as total sugars, free phenol and soluble protein, were assessed spectrophotometrically in two rice ecosystem before and after planthopper infestation. The estimation of biochemical constituents in both ecosystem of rice was done to establish the relationship between various biochemical contents and to compare it with resistance. The results revealed that the higher level of total sugars was observed in TPR ecosystem compared to DSR. The amount of phenols and soluble proteins in DSR was found higher compared to TPR. Total sugar content shows significant positive relationship with plant hoppers in TPR. Whereas, free phenols and soluble protein were showed negative correlation with planthoppers in DSR at 90 DAS. However, the amount of phenol and soluble proteins were related to resistance.

\section{Introduction}

India is one of the world's largest producer of rice (Oryza sativa L.), accounting for 20 per cent of worlds production. Rice is India's important cereal crop and is the staple food of the people of the eastern and southern parts of the country, it is grown over an area of $44.4 \mathrm{~m}$ ha with production of $104.32 \mathrm{~m}$ tonnes (Anon., 2016). Rice is grown mainly by transplanting the seedlings into puddled soil, which require large amount of water and labours. In recent years both are scarce and expensive, making rice production less profitable, also drudgery involved in transplanting is of serious concern. A change from transplanting to direct seeding may affect the status of various pests. The main factors that influence pest status are exposure of very young seedlings to pests, longer crop duration and increased plant density. The brown planthopper (BPH), Nilaparvata lugens (Stal.) and white backed planthopper(WBPH), Sogatella furcifera 
(Horvath) (Hemiptera: Delphacidae) is one of the most serious pests of rice. It damages the plants directly by sucking plant sap and indirectly by transmitting viral diseases like grassy stunt (Ling, 1975) and ragged stunt (Ling et al., 1978). It causes economic damage by sucking phloem sap which in turn leads to hopper burn and severe yield loss (AICRIP, 2008). Even though application of chemical insecticides is commonly practiced to manage $\mathrm{BPH}$, it has not been a satisfactory tactics in practical rice production, because insecticides can cause BPH resurgence and may play a major role in inducing outbreaks (Tanaka et al., 2000). Alternatively, growing of resistant varieties is an economical and efficient way for the management of the pest (Vasanta Bhanu et al., 2014). The biochemical constituents of the rice plants contributing to resistance has been studied from time immemorial. In the present study the biochemical constituents in DSR and TPR ecosystem were compared so as understand the role of biochemical defense.

\section{Materials and Methods}

Field experiment was conducted for two seasons during rabi 2013 at Mallat village of Raichur district and Kharif 2013-14 at Agricultural Research Station, Gangavathi of Koppal district of UAS Raichur, Karnataka under and unprotected condition.

Samples of rice crop were collected separately from DSR and TPR. Chemical compounds like free phenols, total sugars and soluble protein from the plant samples were estimated at different crop stages viz., 30, 60 and 90 DAS.

\section{Extraction of plant tissues in alcohol}

Five gram of fresh tender rice leaf and stem was weighed and cut into small pieces, grounded thoroughly in a mortar with $20 \mathrm{ml}$ of 80 per cent alcohol. Later, it was filtered thorough muslin cloth twice. Then, refiltered through Whatman No 41 filter paper later, extract was stored in a refrigerator at $4^{\circ} \mathrm{C}$ and used for further analysis as given by (Sadasivam and Manickam, 2008). Heavy metals, salts and dark pigments from the extract were precipitated by disodium hydrogen phosphate. Two $\mathrm{ml}$ of saturated lead acetate solution was added drop by drop to 25 $\mathrm{ml}$ of the coloured alcoholic extract with three $\mathrm{ml}$ of saturated solution of disodium hydrogen phosphate till the precipitation was completed. The above solutions were mixed thoroughly and kept overnight. Next day, it was filtered through Whatman No 41 filter paper and volume made up to $25 \mathrm{ml}$ with 80 per cent alcohol and stored in a refrigerator at $4^{\circ} \mathrm{C}$ for further analysis.

\section{Estimation of total sugars}

Estimation of total sugars present in plant samples was estimated by Nelson Somgs method (Nelson, 1994). Fresh leaves (5 g) of plants extract were homogenized in hot 80 per cent ethanol and $10 \mathrm{ml}$ distilled water was added to dissolve the sugars. Reducing sugars were estimated by using DNSA reagent calorimetrically at $510 \mathrm{~nm}$ wavelength and calculated from graph plotted using glucose as a standard.

Non-reducing sugars were estimated using anthrone reagent sample extractant were hydrolysed separately by keeping in boiling water bath for 3 hours with $2.5 \mathrm{~N} \mathrm{HCl}(5 \mathrm{ml})$ and was neutralized with $\mathrm{Na} 2 \mathrm{CO} 3$ after cooling it to room temperature. Volume was made up to $100 \mathrm{ml}$ and Non-reducing sugars were estimated at $610 \mathrm{~nm}$ wavelength on UVvisible spectrophotometer and calculated from graph plotted using glucose as a standard. Total sugars were calculated by using following formula and expressed in $\mathrm{mg} / 100 \mathrm{~g}$ sample. 


\section{Estimation of total Phenol}

Total phenols present in plant samples was estimated by following Folin- Ciocalteau Reagent Method (FCR) (Brays and Thocope, 1954). One $\mathrm{ml}$ of each alcohol extracts was taken in test tubes to which one ml of FolinCiocalteeau reagent and two $\mathrm{ml}$ of sodium carbonate solution $(2 \%)$ were added. The tubes were shaken well and heated in a hot water bath for exactly one minute and then cooled under running tap water. The blue colour developed was diluted to $25 \mathrm{ml}$ with water and its absorbance was recorded at 650 $\mathrm{nm}$ in UV spectrophotometer. The amount of phenols present in sample was calculated from a standard curve prepared from Catechol.

\section{Estimation of soluble Proteins}

Soluble protein present in plant samples was analysed by Lowrys method (Lowry et al., 1951). Plant samples (5 g) were homogenized in $2.5 \mathrm{ml}$ of phosphate buffer $(\mathrm{pH}$ 7.0). The extract was centrifuged for $15 \mathrm{~min}$ at $4^{\circ} \mathrm{C}$ and the supernatant transferred to a tube containing a mixture of $20 \mathrm{ml}$ acetone and 14 $\mathrm{ml} \beta$-Mercaptoethanol for precipitation of protein. The sample tubes were stored at $0^{\circ} \mathrm{C}$ for $5 \mathrm{hr}$ and then centrifuged at $10000 \mathrm{rpm}$ for $20 \mathrm{~min}$. The supernatant was discarded and the pellet dissolved in $2.5 \mathrm{ml}$ sodium hydroxide solution. Aliquot of $0.2 \mathrm{ml}$ from this sample was used to prepare the reaction mixture. The intensity of blue colour developed was recorded at $660 \mathrm{~nm}$ and protein concentration was measured using bovine serum albumin as standard.

\section{Statistical analysis}

Influence of biochemical constituents such as total sugars, free phenol and soluble protein were correlated with the plant hoppers population.

\section{Results and Discussion}

Correlation between total sugar phenols and soluble protein content with incidence of planthoppers during rabi 2013

Total sugar content varied among the different planting methods. Lower concentration of sugar content was observed in direct seeded (16.14 mg/g of sample) than transplanted $(17.26 \mathrm{mg} / \mathrm{g}$ of sample) rice at 30 DAS (Table 1). Non-significant positive correlation between sugar content with brown planthopper $(r=0.87)$ and white backed planthopper $(\mathrm{r}=0.84)$ at 60 DAS was observed in direct seeded rice. Significant and positive correlation between sugar content against brown planthopper $(\mathrm{r}=0.98)$ and white backed planthopper $(\mathrm{r}=0.88)$ at 60 DAS in transplanted rice. Which it was high in transplanted rice condition $(23.04 \mathrm{mg} / \mathrm{g}$ of sample) followed by direct seeded rice (21.33 $\mathrm{mg} / \mathrm{g}$ of sample) at $90 \mathrm{DAS}$.

Positive correlation observed between sugar content with brown planthopper $(\mathrm{r}=0.92)$ and white backed planthopper $(r=0.89)$ in direct seeded rice was noticed. Whereas, in transplanted condition significant positive correlation with brown planthopper $(\mathrm{r}=0.95)$ and white backed planthopper $(\mathrm{r}=0.93)$ was noticed (Table 2).

Maximum phenol content was recorded at 30 DAS in direct seeded ( $2.08 \mathrm{mg} / \mathrm{g}$ of sample) followed by transplanted $(1.94 \mathrm{mg} / \mathrm{g}$ of sample) rice (Table 3). Later gradual decline in the phenolic content in plant tissue was observed. Least phenol content was found 90 days after sowing in transplanted $(1.15 \mathrm{mg} / \mathrm{g}$ of sample) rice followed by direct seeded $(1.34 \mathrm{mg} / \mathrm{g}$ of sample) rice (Table 1). Significant negative correlation with brown planthopper $(\mathrm{r}=-0.30)$ and white backed planthopper $(r=-0.52)$ at 60 DAS in direct seeded and transplanted rice with brown plant 
hopper $(\mathrm{r}=-0.65)$ and white backed plant hopper $(r=-0.76)$. There was significant negative correlation between phenols with brown planthopper $(\mathrm{r}=-0.50)$ and white backed planthopper $(\mathrm{r}=-0.90)$ at 90 DAS in direct seeded rice. Non-significant negative correlation was observed with brown planthopper $(\mathrm{r}=-0.97)$ and white backed planthopper $(\mathrm{r}=-0.96)$ transplanted rice (Table 2).

Soluble protein were found higher when crop attained 30 days in direct seeded rice (5.18 $\mathrm{mg} / \mathrm{g}$ of sample) followed by transplanted rice (4.52 $\mathrm{mg} / \mathrm{g}$ of sample) (Table 1). The minimum concentration of protein was found in transplanted $(2.74 \mathrm{mg} / \mathrm{g}$ of sample) than direct seeded $(3.31 \mathrm{mg} / \mathrm{g}$ of sample) rice at 90 DAS (Table 1). Significant negative correlation between soluble protein with brown planthopper $(\mathrm{r}=-0.15)$ and white backed planthopper $(\mathrm{r}=-0.53)$ in direct seeded rice was seen.

Non-significant negative correlation with brown planthopper $(\mathrm{r}=-0.46)$ and white backed planthopper $(\mathrm{r}=-0.81)$ in transplanted rice at 60 DAS. Negative correlation occurred between soluble protein and brown planthopper $(\mathrm{r}=-0.39)$ and white backed planthopper $(\mathrm{r}=-0.81)$ in direct seeded rice. Whereas, in transplanted condition nonsignificant negative correlation with brown planthopper $(\mathrm{r}=-0.80)$ and white backed planthopper $(\mathrm{r}=-0.77)$ at 90 days after sowing was recorded (Table 2 ).

Correlation between total sugar phenols and soluble protein content with incidence of planthoppers during Kharif 2013-14

Total sugar content at 90 days after sowing was maximum in transplanted rice (18.24 $\mathrm{mg} / \mathrm{g}$ of sample) followed by direct seeded rice $(17.06 \mathrm{mg} / \mathrm{g}$ of sample). Least sugar content was found at 30 DAS in direct seeded rice (12.56 $\mathrm{mg} / \mathrm{g}$ of sample) followed by transplanted rice $(13.27 \mathrm{mg} / \mathrm{g}$ of sample) (Table 3). Total sugar had positive nonsignificant correlation with brown planthopper $(\mathrm{r}=0.73)$ and white backed planthopper $(r=0.87)$ at 60 DAS in direct seeded rice.

Whereas, transplanted rice had significant positive correlation with brown planthopper ( $\mathrm{r}$ $=0.83)$ and white backed planthopper $(\mathrm{r}=$ 0.99). There was non-significant positive correlation between sugars with brown planthopper $(r=0.86)$ and white backed planthopper $(r=0.89)$ at 90 DAS in direct seeded rice. Significant positive correlation with brown planthopper $(\mathrm{r}=0.71)$ and white backed planthopper $(r=0.29)$ in transplanted rice was noticed (Table 4$)$.

The amount of free phenols was highest at 30 DAS in direct seeded rice $(2.18 \mathrm{mg} / \mathrm{g}$ of sample) followed by transplanted rice (1.81 $\mathrm{mg} / \mathrm{g}$ of sample) (Table 3 ). The minimum concentration of phenol was found in transplanted $(1.08 \mathrm{mg} / \mathrm{g}$ of sample) than direct seeded $(1.43 \mathrm{mg} / \mathrm{g}$ of sample) rice at $90 \mathrm{DAS}$ (Table 3).

Significant negative correlation was recorded between free phenol with brown planthopper $(\mathrm{r}=-0.52)$ and white backed planthopper $(\mathrm{r}=$ $0.70)$ in direct seeded rice. Non-significant negative relationship with brown planthopper $(\mathrm{r}=-0.68)$ and white backed planthopper $(\mathrm{r}=$ -0.94) in transplanted rice at 60 DAS was observed. It is evident from the data (Table 4) that there was significant negative correlation between free phenol and brown planthopper $(\mathrm{r}$ $=-0.87)$ and white backed planthopper $(\mathrm{r}=-$ 0.81 ) in direct seeded rice. Whereas, in transplanted condition, non-significant negative correlation with brown planthopper $(\mathrm{r}=-0.93)$ and white backed planthopper $(\mathrm{r}=$ -0.99) at 90 DAS was observed. 
Table.1 Influence of different planting methods on the biochemical parameter of rice plants during rabi 2012-13

\begin{tabular}{|c|l|c|c|c|}
\hline $\begin{array}{c}\text { Observation } \\
\text { Period }\end{array}$ & Planting method & $\begin{array}{c}\text { Total sugar } \\
(\mathbf{m g})\end{array}$ & $\begin{array}{c}\text { Free phenols } \\
(\mathbf{m g})\end{array}$ & $\begin{array}{c}\text { Soluble } \\
\text { protein (mg) }\end{array}$ \\
\hline \multirow{2}{*}{$30 \mathrm{DAS}$} & Direct seeded rice & 16.14 & 2.08 & 5.18 \\
\cline { 2 - 5 } & Transplanted rice & 17.26 & 1.94 & 4.52 \\
\hline \multirow{2}{*}{$60 \mathrm{DAS}$} & Direct seeded rice & 18.52 & 1.89 & 4.26 \\
\cline { 2 - 5 } & Transplanted rice & 19.73 & 1.47 & 3.76 \\
\hline \multirow{2}{*}{$90 \mathrm{DAS}$} & Direct seeded rice & 21.33 & 1.34 & 3.31 \\
\cline { 2 - 5 } & Transplanted rice & 23.04 & 1.15 & 2.74 \\
\hline
\end{tabular}

Mean of 10 plants DAS: Day After Sowing

Table. 2 Correlation between biochemical parameter of rice plants and incidence of insect-pests during rabi 2012-13

\begin{tabular}{|c|c|c|c|c|c|c|c|c|c|c|c|c|}
\hline \multirow{3}{*}{$\begin{array}{l}\text { Planting } \\
\text { method }\end{array}$} & \multicolumn{4}{|c|}{ Total sugars (mg) } & \multicolumn{4}{|c|}{ Free phenols (mg) } & \multicolumn{4}{|c|}{ Soluble protein (mg) } \\
\hline & \multicolumn{2}{|c|}{60 DAS } & \multicolumn{2}{|c|}{90 DAS } & \multicolumn{2}{|c|}{60 DAS } & \multicolumn{2}{|c|}{90 DAS } & \multicolumn{2}{|c|}{60 DAS } & \multicolumn{2}{|c|}{90 DAS } \\
\hline & $\begin{array}{c}\text { BPH/ } \\
\text { hill }\end{array}$ & $\begin{array}{c}\text { WBPH } \\
\text { / hill }\end{array}$ & $\begin{array}{c}\text { BPH/ } \\
\text { hill }\end{array}$ & $\begin{array}{c}\text { WBPH/ } \\
\text { hill }\end{array}$ & $\begin{array}{c}\text { BPH/ } \\
\text { hill }\end{array}$ & $\begin{array}{c}\text { WBPH/ } \\
\text { hill }\end{array}$ & $\begin{array}{c}\text { BPH/ } \\
\text { hill }\end{array}$ & $\begin{array}{c}\text { WBPH/ } \\
\text { hill }\end{array}$ & $\begin{array}{c}\text { BPH/ } \\
\text { hill }\end{array}$ & $\begin{array}{c}\text { WBPH } \\
\text { / hill }\end{array}$ & $\begin{array}{c}\text { BPH/ } \\
\text { hill }\end{array}$ & $\begin{array}{c}\text { WBPH/ } \\
\text { hill }\end{array}$ \\
\hline $\begin{array}{l}\text { Direct } \\
\text { seeded rice }\end{array}$ & 0.875 & 0.847 & 0.927 & 0.892 & $-0.300 *$ & $-0.526^{*}$ & $-0.500 * *$ & $-0.908 * *$ & $-0.158 *$ & $-0.533 *$ & $-0.397 *$ & $-0.815^{*}$ \\
\hline $\begin{array}{l}\text { Transplanted } \\
\text { rice }\end{array}$ & $0.981 * *$ & $0.881 *$ & $0.954 *$ & $0.936^{*}$ & -0.656 & -0.766 & -0.969 & -0.967 & -0.469 & -0.811 & -0.806 & -0.778 \\
\hline
\end{tabular}


Table.3 Influence of different planting methods on the biochemical parameter of rice plants during kharif 2013

\begin{tabular}{|c|c|c|c|c|c|c|c|c|c|}
\hline \multirow[b]{3}{*}{ Planting method } & \multicolumn{9}{|c|}{ kharif 2013} \\
\hline & \multicolumn{3}{|c|}{ Total sugar (mg) } & \multicolumn{3}{|c|}{ Free phenols (mg) } & \multicolumn{3}{|c|}{ Soluble protein (mg) } \\
\hline & 30 DAS & 60 DAS & 90 DAS & 30DAS & 60 DAS & 90 DAS & 30DAS & 60 DAS & 90 DAS \\
\hline Direct seeded rice & 12.56 & 14.83 & 17.06 & 2.18 & 1.75 & 1.43 & 4.90 & 3.35 & 2.82 \\
\hline Transplanted rice & 13.27 & 16.28 & 18.24 & 1.81 & 1.23 & 1.08 & 4.12 & 3.20 & 2.41 \\
\hline
\end{tabular}

DAS: Day After Sowing

Table.4 Correlation between biochemical parameter in rice plants and incidence of insect-pests during kharif 2013

\begin{tabular}{|c|c|c|c|c|c|c|c|c|c|c|c|c|}
\hline \multirow{3}{*}{ Planting method } & \multicolumn{4}{|c|}{ Total sugars (mg) } & \multicolumn{4}{|c|}{ Free phenols (mg) } & \multicolumn{4}{|c|}{ Soluble protein (mg) } \\
\hline & \multicolumn{2}{|c|}{60 DAS } & \multicolumn{2}{|c|}{90 DAS } & \multicolumn{2}{|c|}{60 DAS } & \multicolumn{2}{|c|}{90 DAS } & \multicolumn{2}{|c|}{60 DAS } & \multicolumn{2}{|c|}{90 DAS } \\
\hline & $\begin{array}{c}\text { BPH/ } \\
\text { hill }\end{array}$ & $\begin{array}{c}\text { WBPH/ } \\
\text { hill }\end{array}$ & $\begin{array}{c}\text { BPH/ } \\
\text { hill }\end{array}$ & $\begin{array}{c}\text { WBPH/ } \\
\text { hill }\end{array}$ & $\begin{array}{c}\text { BPH/ } \\
\text { hill }\end{array}$ & $\begin{array}{c}\text { WBPH/ } \\
\text { hill }\end{array}$ & $\begin{array}{c}\text { BPH/ } \\
\text { hill }\end{array}$ & $\begin{array}{c}\text { WBPH/ } \\
\text { hill }\end{array}$ & $\begin{array}{c}\text { BPH/ } \\
\text { hill }\end{array}$ & $\begin{array}{c}\text { WBPH/ } \\
\text { hill }\end{array}$ & $\begin{array}{c}\text { BPH/ } \\
\text { hill }\end{array}$ & $\begin{array}{c}\text { WBPH } \\
\text { hill }\end{array}$ \\
\hline Direct seeded rice & 0.731 & 0.873 & 0.866 & 0.892 & $-0.522 *$ & $-0.701 *$ & $-0.878 *$ & $-0.810^{*}$ & $-0.986 * *$ & $-0.859 *$ & $-0.204^{*}$ & $-0.814^{*}$ \\
\hline Transplanted rice & $0.834^{*}$ & $0.990 * *$ & $0.713 * *$ & $0.296^{*}$ & -0.683 & -0.946 & -0.931 & -0.998 & -0.643 & -0.126 & -0.831 & -0.375 \\
\hline
\end{tabular}


Soluble protein content varied among the different planting methods. Protein concentration was comparatively high in direct seeded rice condition $(4.90 \mathrm{mg} / \mathrm{g}$ of sample) followed by transplanted condition $(4.12 \mathrm{mg} / \mathrm{g}$ of sample) at $30 \mathrm{DAS}$. The lower concentration of protein content was noticed in transplanted rice $(2.41 \mathrm{mg} / \mathrm{g}$ of sample) than direct seeded rice $(2.82 \mathrm{mg} / \mathrm{g}$ of sample) at 90 DAS (Table 3). Significant negative correlation between protein content with brown planthopper $(\mathrm{r}=-0.98)$ and white backed planthopper $(r=0.85)$ at 60 DAS in direct seeded rice was noticed. Nonsignificant negative correlation between protein content against brown planthopper $(\mathrm{r}$ $=-0.64)$ and white backed planthopper $(\mathrm{r}=-$ 0.12 ) at $60 \mathrm{DAS}$ in transplanted rice was seen. At 90 days after sowing significant negative correlation between protein content with brown plant hopper $(\mathrm{r}=-0.20)$ and white backed planhopper $(\mathrm{r}=-0.81)$ in direct seeded rice was found. Whereas, in transplanted condition, non-significant negative correlation with brown planthopper $(\mathrm{r}=-0.83)$ and white backed planthopper $(r=-0.37)$ was seen (Table 4).

Sugar content was very low initially at 30 days old crop it was increased gradually and reached at higher level in direct seeded rice (21.33 and $17.06 \mathrm{mg} / \mathrm{gram})$ and transplanted situation (23.04 and $18.24 \mathrm{mg} / \mathrm{gram}$ ) in both the planting methods at 90 DAS. When crop attained maturity the accumulation of starch and sugar content was higher in plants. This had significant positive correlation with $\mathrm{BPH}$ and WBPH in transplanted rice. Similarly, non-significant positive correlation between sugar content with BPH and WBPH in direct seeded rice. Due to higher concentration of total sugars content in transplanted rice than the direct seeded rice, more planthoppers infestation was seen in transplanted situation. Similar findings observed by the Muhammad Salim (2002) and Yolanda Chen (2009) who reported that sugar content act as feeding stimulants for sap feeders, there is some evidence that the chemical composition of the rice plant can influence BPH feeding behaviour. At different crop growth stages free phenol content varied from higher level to lower level. Initial 30 days old crop had higher concentration of phenol content was found in direct seeded rice compare to transplanted rice later gradually decline. Minimum concentration of phenol was found in transplanted rice which had non-significant negative correlation with planthoppers at 90 DAS was observed. Phenol content act as chemical barriers against insect pests damage. The present findings are in close conformity with Mohan et al., (1988); Rath and Misra (1998) and Chandramani et al., (2009) they reported high phenol content in rice is negatively correlated with the incidence of the WBPH and BPH.

Soluble protein content varied among the different planting methods. Protein concentration was comparatively high in direct seeded rice condition followed by transplanted condition. At 90 days after sowing significant negative correlation between protein content with BPH and WBPH in direct seeded rice was found. Similarly, in transplanted situation nonsignificant negative correlation with BPH and WBPH. Punithavalli et al., (2013) who reported that there was a slight decrease in the protein content invariably in the infested plants compared with the healthy plants. Moreover, plant biochemical defense being a dynamic system, more estimation of constituents and correlation of their concentration with resistance, could only be suggestive, but not decisive.

\section{Acknowledgements}

The authors are grateful to Mr. R.V. Beladhadi, Department of Soil Science and 
Agril. Chemistry, College of Agriculture, Raichur for their timely help extended to me in completing the task undertaken.

\section{References}

Anonymous, 2016 , http://agricoop.nic.in/agristatistics.htm.

Brays, H. G., and Thorope, W. Y., 1954. Analysis of phenolic compounds of interest in metabolim. In: Moth Biochem. Annual. Edu., Intersarnoe publishing Inc., New York, 1: 27-52.

Chandramani, P., Rajendran, R., Sivasubramanian, P. and Muthiah, C., (2009). Management of hoppers in rice through host nutrition a novel approach. J. Biopest., 2(1): 99-106.

Ling, K. C., 1975, Rice virus diseases. International Rice Research Institute, Los Banos, Philippines.

Ling, K. C., Tiongco, E. R. and Aguiero, V. M., 1978. Rice ragged stunt: A new virus disease. Plant Disease Report, 62:701- 705 .

Lowry, O. H., Rosebrough, N. J., Farr, A. L. and Randall, R. J., 1951. Protein measurement with the Folin phenol reagent. J. Biol. Chem., 193(1): 265.

Mohan, S., Purushothaman, D., Jayaraj, S. and Rangarajan A. V., 1988. PAL-ase activity in roots of Sorghum bicolor (L.) inoculated with Azospirillum. Curr. Sci., 57: 492-493.

Muhammad Salim, 2002. Effects of potassium nutrition on growth, biomass and chemical composition of rice plants and on host-insect interaction. Pak. J. Agric. Res., 17(1): 155-156.

Nelson, N., 1994. A photometric adaptation of the Somogy's method for determination of glucose. J. Bol. Chem., 153: 375-380.

Punithavalli, M., Muthukrishnan. and Balaji, R., 2013. Defensive responses of rice genotypes for resistance against rice leaf folder. Rice Sci., 20(5): 363-370.

Rath, L. K., and Mishra, D. S., 1998. Biochemical basis of resistance in rice to white backed plant hopper, Sogatella furcifera (Horvath). Envi. Ecol., 16: 361-364.

Sadasivam, S., and Manickam, A., 2008. Biochemical methods, New Age International (P) Limited Publishers, New Delhi, pp. 270.

Tanaka, K., Endo, S. and Kazano, H., 2000. Toxicity of insecticides to predators of rice planthoppers: spiders, the mirid bug and the drynid wasp. Applied Entomology and Zoology, 35: 177- 187.

Vasanta Bhanu, K., Jhansi Lakshmi, V., Katti, G. and Vishnuvardhan Reddy, A. 2014. Antibiosis and tolerance mechanisms of resistance in rice varieties carrying brown planthopper resistance genes. $J$. Biol. and Life Sci., 3: 108-113.

Yolanda H., Chen, 2009. Planthoppers: new threats to the sustainability of intensive rice production systems in Asia. Los Baños (Philippines): International Rice Research Institute. pp 315-326.

\section{How to cite this article:}

Ashrith, K.N., A.G. Sreenivas, G.S. Guruprasad, S.G. Hanchinal and Krishnamurthy, D. 2017. Biochemical Basis of Resistance in Rice against Brown and White Backed Planthopper. Int.J.Curr.Microbiol.App.Sci. 6(10): 1699-1706. doi: https://doi.org/10.20546/ijcmas.2017.610.205 